\title{
Socialism and the Possibility of Utopia in Wesker Trilogy
}

\author{
Fazel Asadi Amjad \\ Associate Professor of English Literature, Department of English and Literature \\ Kharazmi University, Iran; Email: asadi@saba.tmu.ac.ir
}

\begin{abstract}
Mohsen Masoomi
Assistant Professor of English Language \& Literature, Department of English, Islamic Azad University Sanandaj Branch, Iran; Email: masoomi.mohsen@outlook.com

Monireh Arvin
\end{abstract}

Ph. D. Student of English Literature, Department of English, Alborz Campus, University of Tehran, Iran Email:smz__mm@yahoo.com

\section{Doi:10.5901/mjss.2016.v7n3s1p296}

\section{Abstract}

Every modern epoch seems to produce a small number of artists whose work provides society with an antidote to the ignorance of its own exhaustion. Arnold Wesker is one of these writers who offer this therapeutic service to an ailing body. The Wesker Trilogy (1960) has charted the gradual fading of Communist faith and youthful energy among a group of Jews in the East End of London (1936-1959). In this article the author has applied sociological approach, remarkably moral and philosophical socialism, to The Wesker Trilogy in order to reveal Wesker's most ambitious achievement and impressive contribution to the English New Wave Theatre and all his working-class audiences. Therefore, the quest for a radically reconfigured socialism, which Wesker articulates with force and passion in The Trilogy, appears by the late 1960s as a quest for survival, not only for the Left itself but for all humankind. Meanwhile, he works to protect human freedom and dignity and to promote a life worth living. Although he follows many of the goals of socialism, he willingly subordinates his socialist principles of solidarity and communal cooperation to defending the rights of the individual. In Wesker's estimation, no political or religious cause-not even Judaism or socialism-is worth the sacrifice of individual liberty. Finally, what is discussed here is Wesker's notion of utopia. He thinks that the belief in the utopian ideal could provide a meaning and order for life.

Keywords: Apathy, Socialism, Utopia, Working Class.

\section{Introduction}

As Peter Buse argues, "The three plays which make up The Wesker Trilogy (1960)-Chicken Soup with Barley, Roots, and I'm Talking about Jerusalem" - were drawn "on Wesker's working-class Jewish background" and "similarly on his own direct experience" (2003, P.1). As an observer, Kenneth Tynan states, "The action of The Trilogy takes place between the middle thirties and the late fifties and has as its background three wars-the Spanish Civil War, the Second World War, and the Cold War" (2007).

"Beginning with the anti-fascist demonstrations in 1936 in London's East End and ending with the Hungarian uprising in 1956," this study via Communist and anti-Fascist policies explores how "the disintegration of political ideology parallels the disintegration of a family" (2007, Tynan). Arnold Wesker in his plays examines the problems of socialism directly, and he comments affectionately, nostalgically on the family ties that lie at the heart of Jewish life. He deals most directly with Jewish subjects, and with socialism and family life as necessary parts of the Jewish scene.

There are many theories about Socialism in The Trilogy. Chicken Soup with Barley handles the Communist aspect, Roots handles the personal aspect, and I'm Talking about Jerusalem is a sort of study in a William Morris' kind of Socialism. Wesker's aims in his plays, according to Buse, "always went beyond a desire to record sympathetically the everyday life of the working-classes. Sometimes verging on the didactic," The Wesker Trilogy sets out to "diagnose the situation of the working-classes and offer a tentative program for change" (2003, Pp.3-4). Wesker's annoyance, as Buse continues, "is at the lack of worthwhile aspiration in his characters, or at their own unwillingness or inability to carry out their most ambitious and utopian dreams" (Ibid, P.4). 
Reading The Trilogy, we observe that "in Chicken Soup with Barley and I'm Talking about Jerusalem the politically active Kahn family possess ideals worth fighting for, but over the course of twenty years, becomes gradually disillusioned as their expectations fail to come to fruition." In the second play, Roots, "through the character of Beatie Bryant, Wesker suggested that the working classes should not be satisfied with mass culture, ... but deserve access to high art and culture" (2003, Buse, P.4).

During The Trilogy the "huge disturbances impinge on a Jewish working-class household, altering their habits of work and thought, and thus determining the course of their lives" (2007, Tynan). Social turmoil makes all characters disappointed, but we still hear the voice of Wesker, rejecting apathy, and their disillusionment in order to establish a valid image of a good life. This article implies the possibility of making a utopia, despite all serious social turmoil and huge disturbances.

\section{Socialism in the First Play, Chicken Soup with Barley}

In The Trilogy Arnold Wesker explored the organization of society in terms of the "aspirations and disillusion of one family, struggling against political imbalance, unthinking ignorance, and personal weakness to establish a valid image of a good life" (Lambert, 1985, P.7). Chicken Soup with Barley, the first of three plays, with interwoven themes about four interwoven families, the Kahns, the Simmonds, the Beales, and the Bryants, was produced at the Belgrade Theatre, Coventry, in 1958. The theme is of those who care, or try to care, in a world that is indifferent. Wesker's Chicken Soup with Barley is about the "decline of idealism and about disillusionment. It happens to be played out through a Jewish working-class family because that was his background, the one through which he experiences the disillusionment" (2003, Buse, P.6).

The central character is a passionate woman, Sarah Kahn, who has three of the Jewish characteristics in excesslove of family, generosity, and idealism-and the play charts three stages in her life. Act one in 1936 shows all her young friends are romantic communists. The Spanish war is at its height. It is the decade of hope. A successful anti-Mosley demonstration is in progress. Sarah can afford to be optimistic about the future and even about her shiftless husband, Harry. After ten years, in act two the war has just ended. Her daughter, Ada, has married an ex-hero of the Party, Dave, who has given up politics. Her husband is in and out of jobs, but mostly out, and her passion is centered on her adolescent son, Ronnie, who aims to be a socialist novelist. In act three, after another ten years, her husband is a permanent invalid. Her comrades are all scattered and Hungary has completed the disillusionment of her son. There's a falling off in the zeal for socialism, and disillusion has crept in, only Sarah keeps her simple faith. She sees Ronnie going the way of her husband, old, tired, disappointed. She still has the fire in her belly. It is the fire not of an ideologue, but of a fighter: "I fought everybody who didn't care" (Wesker, 1964, P.74). But Wesker does not idealize or romanticize. Sarah emerges as a particular woman who loves humanity at the expense of those near her. Not that she neglects her family. According to Frederick Lumley, Wesker at any rate remains in his "land of make believe" (1967, P.283), not that of imagination and emotion, but rather of "sentimentalism and class security" (1967, P.283).

Throughout the three acts, Sarah remains firm in her convictions, but gradually the children begin to follow in their father's footsteps. First Ada becomes disillusioned with politics and goes off to start a new life in the country with her equally disillusioned husband, Dave, and then Ronnie, himself enthusiastic enough in the second act, gets by 1956 equally disillusioned: "I've lost my faith and I've lost my ambition" (Wesker, 1964, P.72).

In the play's final scene, we see Ronnie return while he is ten years older and terribly disillusioned with the devastation of International Communism. Boiling over with indignation about the action of Soviet Russia in quelling the revolution in Hungary, Ronnie is on fire to confront Sarah with his indignation. "Once optimistic about the Socialist party and nationalization," as Reade Dornan in Wesker Revisited asserts, "he has become disgusted with political institutions" (1994, P.29). The language Ronnie uses is facile and rhetorical. "What's happened to us? Were we cheated or did we cheat ourselves? And the terrifying thing is-I don't care either. And the great ideal you always cherished has exploded in front of your eyes. But you won't face it" (Wesker, 1964, P.72). Sarah cannot understand why he is attacking the core of her beliefs in the strength of the family and in the basically humane values of the party. All Sarah can say about it is that she too is hurt by what has happened in Hungary. But then the focus shifts from public politics to her private need for political involvement-which Sarah equates with a need to fight the kind of apathy she associates with Harry. Under the pressure that has been built up by a highly theatrical argument, she tells a story about a Jewish neighbor whose chicken soup with barley saved Ada from dying of diphtheria. Finally, his resignation infuriates Sarah, who shouts at him, "So? Nothing! Despair-die then! ... Ronnie, don't let me finish this life thinking I lived for nothing. We got scars but we got through. You've got to care, you've got to care or you'll die" (Wesker, 1964, P.75).

One way to appreciate Chicken Soup with Barley, according to Riley and Mendelson, is that "the political issues 
are almost inseparable from Wesker's characters" and they "seem as much a part of the household as a cup of tea" (1976, P.482). Wesker's great themes, according to Riley and Mendelson, are "death and the family" (1976, P.484). To be fair, according to John Wakeman, Sarah has kept her faith less in an abstract theory of communist, than in her fellow humans (1975, P.1528): "There will always be human beings and as long as there are there will always be the idea of brotherhood. Please, Ronnie, don't let me finish this life thinking I lived for nothing. We got scars but we got through" (Wesker, 1964, P.75).

According to Wesker, Chicken Soup with Barley was "a desperate attempt to rise above the despair which grew out of a sense of betrayal by the World's politicians in general, and the Labor Government and the Soviet Union in particular" (Incited in Wakeman, 1975, P.1527). Dornan asserts that Wesker has always "favored the concerns of the individual over abstract conception of collective political action" (1994, P.4). In these terms, he has always been an individualist, though for most of his career, "his individualism has been qualified by a preoccupation with the necessity and value of human relations" (Ibid).

\section{Socialism in the Second Play, Roots}

Roots, the middle play of Wesker's trilogy, does not deal directly with the Kahn family or with Leftist politics at all. Roots is the story of Ronnie and his girlfriend, Beatie Bryant, but Ronnie is an off-stage figure. Although Beatie is constantly quoting him, the audience never sees him. Ronnie, a frank characterization of Wesker himself, is the pastry cook whose affair with Beatie Bryant is the basis for Roots.

Roots is the most powerful and eloquent of the three dramas; it most clearly expresses Wesker's sense of dismay over the indifference of the working class toward improving itself and finding its own voice. Where Chicken Soup with Barley covers a large tract of time and handles a number of changing, developing characters, Roots occupies only a fortnight and concentrates almost entirely upon one character, Beatie Bryant (Taylor, 1963, P.135). Beatie is a girl Ronnie has met and becomes engaged to in London, but "her home is deep in Norfolk and her people are farm-workers" (Ibid). She comes home without him, but he is to follow later, and meanwhile she has time to explain about him and his ideas to her people, and incidentally to realize to the full how far her people fall short of them. But she herself is still in transition. Though she obediently paints abstracts and has learnt to say all the right things about them, though she "has picked up all Ronnie's ideas about classical music, popular culture, and human relationships" (Ibid), all she can do is to parrot them; she does not really understand, though she is pathetically willing to learn. In one of her imitative moments, Beatie conveys Ronnie's definition of socialism to her mother: "Socialism isn't talking all the time, it's living, it's singing, it's dancing, it's being interested in what go on around you, it's being concerned about people and the world" (Wesker, 1964, P.129).

In the last act it emerges to devastating effect when the news arrives that Ronnie is not coming and has decided that marriage between him and Beatie would not work. Mrs. Bryant does not care that Beatie is suffering; all that concerns her is that she has been proved right and her daughter wrong, that after all "The apple don't fall far from the tree" (Wesker, 1964, P.144), and Beatie, though she may give herself airs and think she is better than the rest of them, cannot really escape. But this shows she is more wrong! For partly in reaction to the news of Ronnie's defection, Beatie does begin to think for herself, to speak for herself: she sees the falsity of Ronnie's ideas about country workers, living in mystic communion with nature, but sees, too, that their present abject condition is their own fault: "The whole stinkin' commercial world insults us and we don't care a damn. Well, Ronnie's right-it's our own bloody fault. We want the thirdrate-we got it!" (Wesker, 1964, P.148) Transported with her own sudden flew of eloquence, Beatie cries out as the curtain falls: "...God in heaven, Ronnie! It does work, it's happening to me; I can feel it's happened, I'm beginning, on my own two feet, I'm beginning ..." (Ibid). The final stage direction assures us that "whatever she will do her family will continue to live as before, but she stands alone-articulate at last" (Ibid).

Robert Wilcher in his Understanding Arnold Wesker argues that it is typical of Wesker's insight, and vital to the complexity of the final scene, that the unexpected arrival of Ronnie's letter should "trigger an unusual degree of articulateness" (1991, P.49) in the mother, as well as in the daughter who has spent much of the past fortnight finding fault with the world in which she grew up. Wilcher continues, "The shock of the slap that she administers to Beatie's face releases Mrs. Bryant's pent up feelings of hurt and resentment and frustration" (Ibid). Beatie learns that this is difficult and requires "much effort" (Wesker, 1964, P.146), but it is also the only way of finding one's identity, one's "roots" (Ibid). One will never find a fixed identity, or a predetermined one, or one that provides complete peace and happiness. On the contrary, "it's asking questions, all the time" (Wesker, 1964, P.147); it is a permanent quest for meaning and value. Beatie at the end of the play has liberated herself from Ronnie. She no longer quotes him; she speaks for herself. But, again, nobody listens. She is "articulate at last," no longer an infant, but she "stands alone" (Wesker, 1964, P.148). "Thus the 
play," as Peter Müller believes, "ends in an atmosphere of sad irony, not with a cozy resolution but with a conflict that leaves the spectator or reader pondering. It is a new dialogic situation" (1998, P.186).

According to Ronald Hayman, the main point is that although she was less than half alive until she met him, she does not come fully alive until the last five minutes of the play when she is learning how to live without him. "She has digested what he has to teach her and she is speaking with a voice of her own" (1970, P.31). Wesker similarly argues that education begins with a critical awareness of human interaction, and he believes in the "educational process as a first line of defense against oppression" (Incited in Dornan, 1998, P.3). Wesker is more interested in simply "nurturing individual awareness" (Ibid).

According to Kevin Asman, Roots is about "socialism as personal contact" (1998, P.42). As Beatie says, "I'm talking. Jenny, Frankie, Mother-l'm not quoting no more" (Wesker,1964, P.148), and she adds, "It does work, It's happening to me, I can feel it's happened, I'm beginning, on my own two feet-I'm beginning..." (Ibid) She has become a person on her own, and yet Ronnie is, in part, responsible. As Beatie cares and fights and becomes more of a human being, socialism is signified.

Heiner Zimmermann believes that Wesker, however, attributes to art a key function in society, for it can "release the working classes from their cultural inferiority to the educated middle class; art will enlighten them and so bring about their social emancipation" (1998, P.53). Wesker, like Hegel, believes that enlightenment leads to emancipation and social progress. Indeed, Wesker in Roots demonstrates that language and the empowerment of self-education are so potent that they provide Beatie with the means to carry on without Ronnie, even though he is supposed to be the committed intellectual. As Dornan in Wesker Revisited asserts, she no longer needs him to think for her. "Beatie's own words become a bridge to her independence" (1994, P.34). In the end of I'm Talking About Jerusalem, Ronnie's brother-in-law, Dave, remarks to Ronnie that he had not the courage to "see a sordid love affair through" (Wesker, 1964, P.216), meaning Ronnie's relationship with Beatie. Ronnie replies, "It wasn't sordid... Beatie Bryant could have been a poem-I gave her words-maybe she became one" (Wesker, 1964, P.216).

Throughout the play Beatie, an uneducated girl from the country, quotes her fiancé Ronnie, former communist intellectual, to provoke her family to think and to question. But at the end, on finding herself jilted, she discovers she has begun to think for herself, as Honora Lynch continues, "Although Beatie triumphs, Roots ends in stoic failure" (1999, P.486). Margaret Drabble comes to the same conclusion, "... the girl survives the traumatic experience of having been ditched by her boyfriend" (1998, P.81). According to Drabble, Wesker's Roots, as his other plays, is "about defiance, about a refusal to accept defeat quietly" (1998, P.81). Wesker says, "My characters are defeated and the reasons for their defeat measure up to a political, a social, an emotional psychological truth-but they are defiant, that's what it is" (Incited in. Ibid). Harold Ribalow adds that in Roots the daughter of the family is "inspired by the socialist doctrine of her absent Jewish lover, loses the lover but-what is made to seem more important-keeps the socialism" (1965, P.109). In the last act, however, when Ronnie jilts Beatie by letter and does not arrive for his expected visit, the girl, in arguing with her family, suddenly discovers herself.

"In Roots, through the character of Beatie Bryant," Wesker suggested that "the working classes should not be satisfied with mass culture-'the slop singers and pop writers'-but deserve access to high art and culture" (Incited in Buse, 2003, P.4). Beatie tells them that radio, television, and the movies are the easy way out: "Anything so long as we don't have to make an effort" (Wesker, 1964, P.147). She continues that "education is not only books and music, but" it is "asking questions, all the time (Ibid). "There are millions of us, all over the country and no one is asking questions, we're all taking the easiest way out. We don't fight for anything, we're so mentally lazy..., we are dead!" (Ibid) She believes that people like her family are an easy market for the third-rate and the commercial.

From the current sociological angle, as Carolyn Riley and Phyllis Carmel Mendelson in Contemporary Literary Criticism argue, "Beatie Bryant is a working-class girl, newly awakened to the joys of abstract painting, classical music, and extra-marital love" (1976, P.481). Through Wesker's viewpoint "she is all that, and also a creature with a choice between self-realization and absorption by the greedy mass of spenders corrupted by advertising" (Ibid); from her own angle, "she is a woman in love who has done her best to reconcile her boy-friend's view of life with that of her mother" (lbid).

"Wesker," as Honora M. Lynch argues, "depicted the defeat of his lower-class characters," dramatizing them "constantly eating without really living" (1999, P.486). Cooking and eating were so predominant in his early plays that they became a "dramatic image for the earthbound, brutish part of man that keeps him from realizing his potential" (Ibid). "While he is entirely committed to the view that the people of his own working class are deprived of the good things of life by various kinds of exploitation," as A. C. Ward concludes, "Wesker sees their own short-comings and is not misled into class-conscious romanticism;" they are "debauched by materialism and its by-product cynicism, but also by inherent weaknesses in their own character" (1964, p.141). 


\section{Socialism in the Third Play, l'm Talking about Jerusalem}

I'm Talking about Jerusalem, which rounds out the Wesker Trilogy, is a drama of exciting and original ideas. The 'Jerusalem' of the title is not the Jerusalem in Israel but the new Jerusalem of William Morris, who believed in the idealism of socialism. Clearly, too, the title was drawn from William Blake's lines: "Till we have built Jerusalem/ In England's green and pleasant land" (Kenney and Gioia, 1998, P.804).

Dave Simmonds and Ada Kahn become disillusioned with "the splendid and heroic working class" (Wesker, 1964, P.42), and decide to cultivate their own version of socialism in the countryside, where they plan to escape the consequences of industrial capitalism by producing handmade furniture, in effect reviving ancient traditions of craftsmanship and self-sufficiency. In this play we take up again the story of Ada and Dave, who set off for the Cotswolds in act two of Chicken Soup with Barley to live a life of Morrisian devotion to arts and crafts, to individual toil in which a man can be his own master away from the domination of the industrialist, the machine, the easy life, and the comforts of electricity. In Sarah's view, Ada and Dave are running away from Socialism to an ivory tower, but for Dave it is an experiment in Socialism on the level of personal and family relationships.

I'm Talking about Jerusalem, according to Glenda Leeming, spans the years 1946-1959. Therefore, It "runs concurrently with the latter part of Chicken Soup with Barley and the whole of Roots, ending with an epilogue in which Dave moves from London to a desolate part of Norfolk so that he could make handcrafted furniture away from the industrial rat race and build the new Jerusalem, severing themselves from industrial society to create an ideal of harmonious unity between work, family life, and nature" (Leeming, 1985, Pp.19-20). Frederick Lumley in his New Trends in $20^{\text {th }}$ Century Drama argues that "I'm talking about Jerusalem is the story of the defeat of Dave's rustic dream. Machines and the city brutalize and make men strangers to one another" (1967, P.280), so Dave has come to the country to find joy and brotherhood in creative work (Incited in 1967, P.280). Dave and Ada, the central characters of I'm Talking about Jerusalem, tried to build a New Jerusalem, a utopia somewhat like the one William Morris describes in his News from Nowhere. In Morris' book the economic revolution has already taken place, and workers, having rejected modern technology, have discovered the pleasures of handicrafts and the enjoyment of industry for its own sake.

When Sammy, Dave's apprentice, sets higher factory wages against freedom and the satisfaction of craftsmanship, and decides to leave him, Dave tries to convince Sammy with his discovery that we work for pleasure and enjoyment of our creation. Not only does his apprentice, Sammy, decide to leave him to earn more money carrying out repetitive work in a factory, but also his customers either fail to take up their orders or simply fail to place orders because they can buy factory-made goods more cheaply. The drama is that something he wanted to do is not something people wanted to buy.

The play properly begins in the second act, with Dave's dismissal by his employer for a bit of petty pilfering and, even more, for lying about it. Thus, as Honora M. Lynch asserts, Dave is revealed as a liar and petty thief who fails at a sort of utopian social experiment. Again, Ronnie despairs. Unanswered for Ronnie is the question "What has worth?" (1999, P.486) Taylor also adds, "It is the warning note: Ada taxes Dave with having brought 'the habits of the factory' with him, and the Colonel asks in genuine puzzlement why they came to the country at all" (1963, P.140). After his dismissal, Dave finds himself alone, striving to make a living as a craftsman, and constantly exposed to the annoying criticism of the locals and his old friends finding his endeavor ridiculous. Having been forced to abandon his own artisan workshop and to compete with a factory culture on its terms, Dave finds himself, inevitably, at the mercy of the bankers to whom he must turn for capital. Thus, their experiment has failed and Dave's moment of vision, in which he decided he was a prophet, has faded with it; now he is defeated, he accepts defeat and sadly but not despairingly recognizes that he is not important. "It will purify itself. The difference between capitalism and socialism: capitalism contained the seeds of its own destruction but socialism contained the seeds of its own purification. Maybe by coming here you've purified yourselves, like Jesus in the Wilderness" (Wesker, 1964, P.211), suggests Ronnie bitterly, but no answer, confirming or denying, is given by anyone present.

Thus, Dave's loss of idealism makes Ronnie desperate. Ronnie, too, has lost his confidence in the future of socialism, but he wants someone to reassure him that visions work. He desperately, and with a passion that overrides mere logic, insists on the need for visions, even in the face of defeat and disillusionment: "They do work! And even if they don't work then for God's sake let's try and behave as though they do-or else nothing will work" (Wesker, 1964, P.216). Eventually, Dave is forced back to London, where of course Sarah is glad to have her family back with her once more. The rustic dream is over. Dave still has the energy, physical and spiritual, to go on, and this demonstration of revival after defeat inspires a sort of resilience even in the mercurial Ronnie, who cups his hands to his mouth and yells in protest to the sky with bitterness, sarcasm, and some venom: "We-must-be-bloody-mad-to cry!" (Wesker, 1964, P.218)

Chicken Soup with Barley ended with the warning that one must care; and I'm Talking about Jerusalem adds that 
one must also learn not to care for opposition and defeat. Glenda Leeming clarifies, "Utopia remains as elusive and remote as ever, yet virtue consists in continuing to strive for it" (1985, P.20). That is the implied conclusion of the trilogy, and the code by which Wesker has gone on writing, it has to be admitted, as vividly and attractively (Ibid). As we considered The Trilogy included plays about the struggle to implement vision and, after the struggle, the defeat of vision; caring for the whole world shrinks to caring for one's own family. Frederick Lumley argues, "Sarah and Ada are the real heroines; they can't change the world themselves, but they lessen the significance of the men's defeat because they carry the seed of hope" (1967, P.278). Wesker does not allow defeat to encompass his ultimate socialist hope (Ibid).

Wilcher concludes that the play opens in 1946 and ends with their packing to return to London in 1959 on a day that "symbolically links the collapse of their personal experiment with the failure of socialist politics at a national level as they hear news on the radio of the Conservative party's election for a third successive term of government" (1991, P.33).

\section{Conclusion}

The Trilogy shows a group of people who are trying in a small way to improve the world and build a better life for themselves, but they are defeated and frustrated by the hard facts of life. It depicts the decline of idealism and disillusionment in "melancholic optimism," not merely sympathizing with everyday life of working class people.

Wesker's vision of life states that the world may be imperfect, society may have failings, but he is concerned with people, and what interests him is that people have their own failings-through lack of conviction, disillusion, and insufficient will power-that make them unable to bring about the better world they aspire to. Wesker's plays are mostly about failure, although they are not depressing either.

His plays are about defiance and refusal to accept defeat quietly, too. "If you don't care, you'll die" (Wesker, 1964, P.76), shouts Sarah Kahn to Ronnie, in the last line of Chicken Soup with Barley, a line which the whole play works towards, through the slow defeats of two decades. Wesker urges us to remain defiant while coping with a defeat in any situation. He invites people to shout back, like his characters after being completely broken. That is why although not optimistic in tone or message, his plays do have certain exhilaration.

What Wesker is trying to do in these three plays is to wake us up. He is telling us that we must learn to have opinions; opinions arrived at by open and flexible minds instead of obstinately held on to narrow-minded ideas. He tells us we can all be artists in greater or lesser degree if we try, and above all he is telling us that we must learn to be articulate.

His idealism has always been tempered by a realistic acknowledgment of the magnitude of the problems that face revolutionary and reformer alike. He has depicted not only the collapse of idealistic projects but also the resilience of the human spirit that keeps idealism alive in the midst of defeat. Thus, the endeavor to achieve utopia in Wesker's plays reflects an emotional reality of their time. Wesker has advocated a revival of the utopian ideal almost in all his works. He was convinced that it could be a means of retrieving hope and showing a way out of a general dilemma. He thinks that the belief in the utopian ideal could provide a meaning and order for life.

\section{References}

Asman, Kevin G. 1998. "The Failure and Promise of 'Socialism as Personal Contact' in Arnold Wesker's Roots." In Arnold Wesker: A Casebook. Ed. Reade W. Dornan. New York: Garland Publishing, Inc., Pp.34-48.

Buse, Peter. 2003. "Author Profile." Time Accessed 24 May 2007. http://www.contemporarywriters.com.

Dornan, Reade W. 1994. Arnold Wesker Revisited: Twayne's English Authors Series. Ed. New York: Twayne Publishers.

--- 1998. "Introduction." In Arnold Wesker: A Casebook. Ed. Reade W. Dornan. New York: Garland Publishing, Inc., Pp.1-10.

Drabble, Margaret. 1998. "Arnold Wesker." In Arnold Wesker: A Casebook. Ed. Reade W. Dornan. New York: Garland Publishing, Inc., Pp.75-88.

Hayman, Ronald. 1970. Contemporary Playwright: Arnold Wesker. London: Heinemann Educational Books Ltd.

Kenney, X. J., and Dana Gioia. 1998. Literature: An Introduction to Fiction, Poetry, and Drama, Vol. 7. Ed. New York: Addison Wesley Longman, Inc.

Lambert, J. W. 1985. "Introduction." In Wesker on File. Ed. Glenda Leeming. London: Methuen London Ltd. Pp.7-13.

Leeming, Glenda. 1985. Wesker on File. London: Methuen London Ltd.

Lumley, Frederick. 1967. New Trends in 20th Century Drama: A Survey since Ibsen and Shaw. London: Barrie and Jenkins Ltd.

Lynch, Honora M. 1999. Encyclopedia of World Literature in the 20 $0^{\text {th }}$ Century. Vol. 4. New York: Longman Group Ltd.

Müller, Klaus Peter. 1998. "Dialogue and Monologic Contexts in Arnold Wesker's Monologues and Monodramas." In Arnold Wesker: A Casebook. Ed. Reade W. Dornan. New York: Garland Publishing, Inc., Pp.179-193.

Ribalow, Harold U. 1965. Arnold Wesker. New York: Twayne Publishers, Inc.

Riley, Carolyn, and Phyllis Carmel Mendelson. 1976. Contemporary Literary Criticism, Vol. 5. Michigan: Gale Research Co.

Taylor, John Russell. 1963. Anger and After: A Guide to the New British Drama. Middlesex: Penguin Books Ltd. 
Tynan, Kenneth. 2007. Wesker Trilogy-"A trilogy which will act as a monument to its era", Daily Mail. http:// www.arnoldwesker.com Wakeman, John. 1975. Biographical Dictionaries in the Authors Series: A Companion Volume to Twentieth Century Authors. Ed. New York: The H. W. Wilson Company.

Ward, A. C. 1964. Twentieth - Century English Literature 1901- 1960. New Fetter Lane: Methuen and Co Ltd.

Wesker, Arnold. 1964. The Wesker Trilogy. Middlesex: Penguin Books Ltd.

Wilcher, Robert. 1991. Understanding Arnold Wesker. Columbia: University of South Carolina Press.

Zimmermann, Heiner O. 1998. "Arnold Wesker and the Desire for Utopia: Utopia's Enemies and Wesker." In Arnold Wesker: A Casebook. Ed. Reade W. Dornan. New York: Garland Publishing, Inc., Pp.49-74. 